\title{
Agrochemical and Pollution Status of Urbanized Agricultural Soils in the Central Part of Yamal Region
}

\author{
Timur Nizamutdinov ${ }^{1}$ (D) Evgeny Abakumov ${ }^{1, *} *$ (D) Eugeniya Morgun ${ }^{2}$, Rostislav Loktev ${ }^{2}$ and Roman Kolesnikov ${ }^{2}$ \\ 1 Department of Applied Ecology, Faculty of Biology, St. Petersburg State University, 16th Liniya V.O., 29, \\ 199178 St. Petersburg, Russia; timur_nizam@mail.ru \\ 2 Arctic Research Center of the Yamal-Nenets Autonomous District, Respublikiv, 20, 629008 Salekhard, Russia; \\ morgun148@gmail.com (E.M.); rost.lok@mail.ru (R.L.); roman387@mail.ru (R.K.) \\ * Correspondence: e_abakumov@mail.ru
}

Citation: Nizamutdinov, T.;

Abakumov, E.; Morgun, E.; Loktev, R.;

Kolesnikov, R. Agrochemical and

Pollution Status of Urbanized

Agricultural Soils in the Central Part

of Yamal Region. Energies 2021, 14,

4080. https://doi.org/

$10.3390 /$ en14144080

Academic Editor: Gleb Kraev

Received: 4 June 2021

Accepted: 2 July 2021

Published: 6 July 2021

Publisher's Note: MDPI stays neutral with regard to jurisdictional claims in published maps and institutional affiliations.

Copyright: (c) 2021 by the authors. Licensee MDPI, Basel, Switzerland. This article is an open access article distributed under the terms and conditions of the Creative Commons Attribution (CC BY) license (https:// creativecommons.org/licenses/by/ $4.0 /)$.

\begin{abstract}
This research looked at the state of soils faced with urbanization processes in the Arctic region of the Yamal-Nenets Autonomous District (YANAO). Soils recently used in agriculture, which are now included in the infrastructure of the cities of Salekhard, Labytnangi, Kharsaim, and Aksarka in the form of various parks and public gardens were studied. Morphological, physico-chemical, and agrochemical studies of selected soils were conducted. Significant differences in fertility parameters between urbanized abandoned agricultural soils and mature soils of the region were revealed. The quality of soil resources was also evaluated in terms of their ecotoxicology condition, namely, the concentrations of trace metals in soils were determined and their current condition was assessed using calculations of various individual and complex soil quality indices.
\end{abstract}

Keywords: Arctic; soil resources; polar urbanization; permafrost; trace metals; nutrients

\section{Introduction}

Nowadays, the majority of countries of the world are faced with new development strategies according to the generally accepted concept of sustainable development. This approach includes many aspects. In 2015, the UN General Assembly developed 17 interconnected goals that are, "a blueprint for achieving a better and sustainable future for all". The Sustainable Development Goals are multifaceted, ranging from poverty eradication to sustainable development partnerships, but most of these goals are related to preserving and improving the quality of the environment [1]. In many ways, the goals of sustainable development are consistent with the principles of rational use of natural resources. Dokuchaev and his disciple Vernadsky made a tremendous contribution to the formation of the modern understanding of rational use of natural resources [2,3]. A special place in the rational use of nature in the works of these scientists was given to soils and their ecological, environment-forming roles in the modern world [4-6]. Academician Vernadsky wrote, "the soil is the noble rust of the Earth", these words reflect the whole essence of the role of soils in the modern world [3]. The soil, located at the interface between the lithosphere, atmosphere, and hydrosphere, plays a fundamental role to ensure the existence of life on planet Earth [7].

Taking into account the importance of soil as the basis for the existence of life, the current attitude of mankind to soil resources is scary. Nowadays soils are recognized as a non-renewable natural resource because if the soil loses its fertile qualities and degrades, it is impossible to return it to its original state within a period that corresponds to the life of one generation [8,9]. According to the FAO, 33\% of the land is currently at different degrees of degradation, and it is also noted that at the current rate of degradation there is a threat to future generations in meeting their nutritional needs [9]. In this context, the words of V.A. Kodva come to mind, which said, " . . degradation and pathology of soils 
cause pathological phenomena in human health, human development, and physiology and even in his mental activity and psyche" [10].

Soil degradation associated with technogenic processes of urbanization is currently of a global nature. Out of 3.3 billion hectares of soil suitable for agricultural use, about 2 billion hectares are in varying degrees of degradation $[7,11]$. Soil degradation occurs as a result of such processes as washout and water erosion, deflation and wind erosion, chemical degradation, reconsolidation, and waterlogging [12-14]. For agricultural soils, there are also processes of dehumification, devegetation, contamination with pollutants of various kinds (carcinogenic compounds, heavy metals, and pesticide residues) [11,15-18].

The enrolling rate of urbanization is also causing soil erosion and degradation. Urban growth has already led to the degradation of huge areas, salinization and contamination of soils with heavy and trace metals, changes in acidity, and the shielding of soils due to the laying of asphalt covers [19-22]. As a rule, urban development occurs gradually and the primary settlements are formed on productive soils. Further development of the city leads to the removal of fertile soils of their agricultural use with the following settlement of these lands for the needs of the city.

Not only giant urban agglomerations are experiencing such phenomena. Surprising as it may be, the Arctic territories have the highest degree of urbanization. Although the population of the Arctic regions does not exceed 2.5 million people, more than $85 \%$ of the people live in cities [23-25]. The cities of the North have a low number of inhabitants, ranging from 20 to 150 thousand people [25]. The largest cities of the Yamal-Nenets Autonomous District (YANAO) have a population of just over 100,000 people-Novy Urengoy (118,033 people) and Noyabrsk (106,911 people) have a population density of 1063 and 2752 people $/ \mathrm{km}^{2}$, respectively. Small and medium-sized towns prevail in YANAO, e.g., Salekhard (51,263 people, 605 people $\left./ \mathrm{km}^{2}\right)$, Labytnangi $\left(26,295\right.$ people, 1195 people $\left./ \mathrm{km}^{2}\right)$, Aksarkovskoye rural settlement (4885 people, 50 people $/ \mathrm{km}^{2}$ ). At the same time, the number of residents per $1 \mathrm{~km}^{2}$ in the whole YANAO is 0.7 people [26].

In the context of a deficiency and strong localization of soil resources, the first Arctic settlers inhabited the most favorable areas in terms of fertility, for example, on the riverbanks. For example, the city of Salekhard, built on the bank of the Ob River, stands on alluvial Quaternary sediments rich in clay particles [27]. This made it possible to do agriculture in Arctic conditions [28-30]. Now, with increasing urbanization and population density, these soils suitable for agriculture are built up in most Arctic cities. This leads to radical transformations of the soil cover and the Arctic geosystems as a whole [25]. It is also important to consider the dispersion of the impact of urbanization in the Arctic region. Due to the so-called "heat island" effect, urbanized ecosystems cause risks of degradation of permafrost in the territory of settlements [31-33]. This may also be one of the causes of climate change as a result of permafrost degradation [34,35]. The anthropogenic load on the cities of the Yamal region is associated not only with traditional factors of influence, such as emissions from industrial plants and motor vehicles. One of the world's largest chromite ores deposits is located near the cities of Labytnangi and Salekhard [36,37]. The ore is extracted by the open-pit method. Naturally, mining leads to the emission of pollutants into the environment, surface waters, and soils [38]. Small towns such as Kharsaim and Aksarka are exposed to local sources of pollution such as combined heat and power plants and emissions from motor vehicles [39].

Our investigation was objected to identify urbanized agricultural soils on the territory of selected cities of the Yamal-Nenets Autonomous District and to assess the degree of their degradation. To estimate the level of nutrient content and basic soil properties in the former agricultural soils subjected to the processes of urbanization (anthropogenic load) and to compare with them the background (mature) soils. The character of pollution of these soils with heavy metals was also assessed. 


\section{Materials and Methods}

\subsection{Key Regional Settings}

The Yamal region's climate is strongly influenced by low temperatures and proximity to the Kara Sea. The region is characterized by a humid continental climate with high relative humidity (up to $90 \%$ ). The annual precipitation is about $350-400 \mathrm{~mm}$, while the annual evaporation is up to $250 \mathrm{~mm}$. Winter lasts up to 7.5 months of the year, with snow cover lasting up to 230 days. The average temperature in January is low to $-25^{\circ} \mathrm{C}$. Spring is very short and cold (about 30 days), with frequent weather changes and frosts. The period of active vegetation lasts only 70 days. The main wind direction in the study area is southwest $(19 \%)$, also northeast $(18 \%)$ and west $(16 \%)$ winds prevail $[40,41]$. The study area is located in the climatic zone of excessive moisture [40-42]. Modern alluvial, lake-alluvial Quaternary sediments of loamy and sandy loam composition represent the parent material of the region $[27,43]$. The mature soils are characterized by a low level of fertility and acidic $\mathrm{pH}$. Soil diversity is represented by taxonomic groups of gleysols, cryosols, and podzols $[28,44]$.

\subsection{Sampling Strategy}

During the field season from 2019 to 2020, soil sampling points were identified in selected YANAO cities. The sampling strategy was based on looking for sites that were previously involved in agriculture and have now been transformed into urban functional areas. As a result, seven soil profile cuts were established in the cities of Salekhard and Labytnangi and the settlements of Aksarka and Kharsaim and their vicinities. Samples were taken from each genetic soil horizon in triplicate and mixed to obtain averaged results for the horizon. The plots settings can be seen in Figure 1.

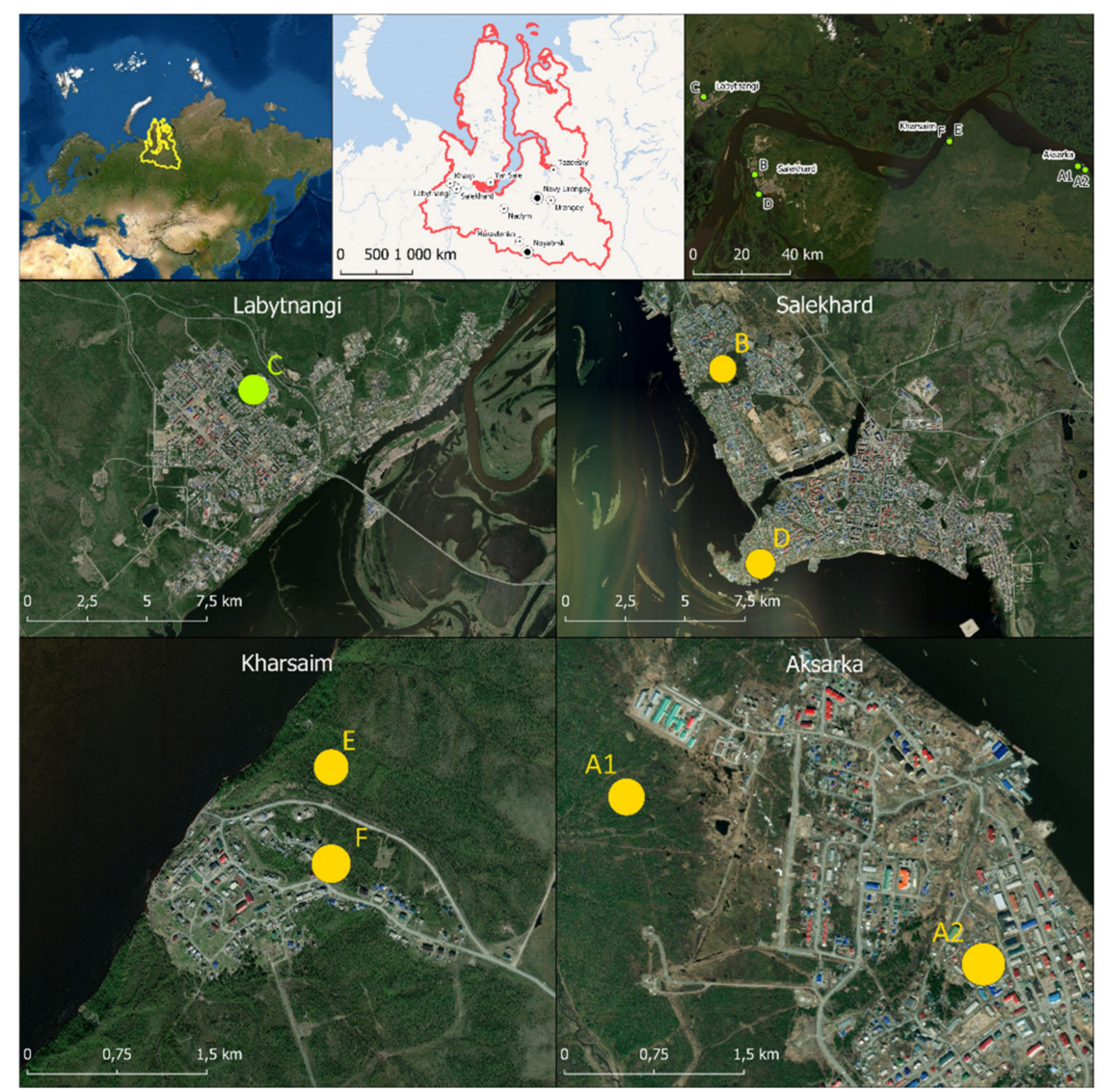

Figure 1. Sampling map of the study area: $(\mathbf{A 1}, \mathbf{E}, \mathbf{F})-$ mature soils; $(\mathbf{A} 2, \mathbf{B}, \mathbf{C}, \mathbf{D})-$ anthropogenic loaded soils. 
The soils studied were described according to the international soil classification system [45]. Descriptions of sampling sites and soil names are given in Table 1. A total of 25 soil samples were collected.

Table 1. Site descriptions and soil types of each sampling point.

\begin{tabular}{|c|c|c|c|}
\hline Sample Code & Site Description & Location & Type of Soil [45] \\
\hline \multicolumn{4}{|c|}{ Urbanized agricultural soils (anthropogenic loaded) } \\
\hline $\mathrm{A} 2$ & Aksarka, former vegetable garden & $\begin{array}{l}\text { N67.800744 } \\
\text { E66.559405 }\end{array}$ & Cryosol \\
\hline B & Salekhard city, former vegetable garden & $\begin{array}{l}\text { N66.575843 } \\
\text { E66.552307 }\end{array}$ & $\begin{array}{l}\text { Podzol } \\
\text { Entic }\end{array}$ \\
\hline $\mathrm{C}$ & Labytnangy city, vegetable garden & $\begin{array}{c}\text { N66.3870104 } \\
\text { E66.6665518 }\end{array}$ & $\begin{array}{l}\text { Podzol } \\
\text { Entic }\end{array}$ \\
\hline $\mathrm{D}$ & Salekhard city, park & $\begin{array}{l}\text { N66.5913085 } \\
\text { E66.5233259 }\end{array}$ & $\begin{array}{l}\text { Technosol } \\
\text { Urbic }\end{array}$ \\
\hline \multicolumn{4}{|c|}{ Mature soils } \\
\hline A1 & Vicinities of Aksarka, mature soil in a larch forest stand & $\begin{array}{l}\text { N67.773559 } \\
\text { E66.564539 }\end{array}$ & $\begin{array}{c}\text { Cryosol } \\
\text { Reductaquic }\end{array}$ \\
\hline $\mathrm{E}$ & Vicinities of Kharsaim, mature soil & $\begin{array}{l}\text { N67.2983804 } \\
\text { E66.6041101 }\end{array}$ & $\begin{array}{l}\text { Podzol } \\
\text { Folic }\end{array}$ \\
\hline $\mathrm{F}$ & Vicinities of Kharsaim, mature soil, tundra & $\begin{array}{l}\text { N67.298325 } \\
\text { E66.601346 }\end{array}$ & $\begin{array}{l}\text { Gleysol } \\
\text { Histic }\end{array}$ \\
\hline
\end{tabular}

\subsection{Laboratory Analyses and Data Processing}

Soil samples were air-dried and transported to the laboratory of the Applied Ecology Department of St. Petersburg State University. Before the laboratory analysis, the samples were grounded and sieved through a $2 \mathrm{~mm}$ sieve to separate the fine-grained fraction.

The $\mathrm{pH}$ values of soil extracts were measured by using a $\mathrm{pH}$-meter-millivoltmeter $\mathrm{pH}$ 150MA (Belarus). Soil solution was prepared in the ratio of $1: 2.5$ with water or $1 \mathrm{M} \mathrm{CaCl}_{2}$ (for mineral soils the optimal soil weight for solution preparation is $8 \mathrm{~g}$ ) [46]. Soil color was determined using the Mansell Colorimetric System. Basal respiration was evaluated by measuring $\mathrm{CO}_{2}$ in Sodium Hydroxide 0.1 molar solution. Incubation of $\mathrm{CO}_{2}$ was conducted for 10 days in plastic sealed containers [47]. The percentage of clay fraction was determined by the sedimentation method $[48,49]$.

The total carbon and nitrogen contents were evaluated using a CHN analyzer (Leco CHN-628; Leco Corporation, St. Joseph, MI, USA).

Main agrochemical characteristics such as mobile phosphorus and potassium and forms of nitrogen were determined using the standard procedures according to GOST 54,650-2011 (for evaluation of available phosphorus and potassium contents) and GOST 26,489-85 (for evaluation of ammonium nitrogen content) - Nessler colorimetric method and Chirikov method. As standard solutions were used calibration reference solutions: $\mathrm{P}_{2} \mathrm{O}_{5}$ from 0 to $50 \mathrm{mg} \times \mathrm{dm}^{-3} ; \mathrm{K}_{2} \mathrm{O}$ from 0 to $100 \mathrm{mg} \times \mathrm{dm}^{-3}$; nitrogen from 0 to $24 \mathrm{mg} \times \mathrm{dm}^{-3}$. The procedure for measuring ammonium nitrate requires its extraction from the soil with potassium chloride solution. Quantitative determination of ammonium is carried out using photometry of colored solutions [50]. The determination of the available forms of phosphorus and potassium is based on the extraction of the compounds described above with hydrochloric acid (acid concentration $0.2 \mathrm{~mol} / \mathrm{L}$ ). After extraction, the quantitative determination of mobile phosphorus and potassium compounds is carried out by photometry methods [51].

The content of trace metals was determined following to the standard ISO 110471998 "Soil Quality-Determination of Cadmium (Cd), Cobalt (Co), Copper (Cu), Lead (Pb), Manganese (Mg), Nickel (Ni) and Zinc (Zn) in Aqua Regia Extracts of Soil-Flame and 
Electrothermal Atomic Absorption Spectrometric" method at Atomic absorption spectrophotometer Kvant 2M (Moscow, Russia). According to this methodology and the instrument's datasheet, the lower detection limit for the metals to be detected is as follows: $\mathrm{Pb}-0.05 ; \mathrm{Cr}-0.02 ; \mathrm{Cu}-0.01 ; \mathrm{Cd}-0.005 ; \mathrm{Ni}-0.02 ; \mathrm{Zn}-0.01 ; \mathrm{As}-0.01 \mathrm{mg} \times \mathrm{kg}^{-1}$. Standard samples of solutions with metal concentrations from 0.1 to $2 \mathrm{mg} \times \mathrm{cm}^{-3}$ were used to calibrate the spectrophotometer [52].

To assess the fertility qualities of the soil, it is essential to know the quantitative content of available forms of phosphorus, potassium, and nitrogen in the soil profile. The content of these elements is extremely important in terms of planning agricultural activities [53-55]. However, the use of soils for agriculture can be limited due to soil contamination with trace metals such as $\mathrm{Pb}, \mathrm{Cd}, \mathrm{Zn}, \mathrm{Ni}, \mathrm{As}$, and $\mathrm{Cu}$. These elements have carcinogenic and mutagenic effects and are detrimental to human health and plant conditions [56-59].

To assess the degree of contamination of soils with trace metals, several qualitative soil indices were calculated. The Geoaccumulation Index (Igeo) allows us to classify seven levels of soil contamination, from Practically unpolluted (Igeo $\leq 0$ ) to Extremely polluted (Igeo > 5) $[60,61]$. The generic calculation formula is as follows:

$$
I_{\text {geo }}=\log _{2}\left[\frac{C_{n}}{1.5 B_{n}}\right]
$$

where: $C_{n}$-the measured concentration of the element in soil, $B_{n}$-the geochemical background value.

Single Pollution Index $(P I)$ is used to calculate some other soil pollution indices, such as Pollution Load Index (PLI) and Potential ecological risk (RI) [62]. The basic formula is as follows:

$$
P I=\frac{C n}{G B}
$$

where: $C_{n}$-the content of heavy metal in soil and $G B$-values of the geochemical background.

Pollution Load Index (PLI) is calculated as a geometric average of PI values [62,63]. The basic formula for calculating this complex index is as follows:

$$
P L I=\sqrt[n]{P I_{1} \times P I_{2} \times P I_{3} \times \ldots P I_{n}}
$$

where: $n$-the number of analyzed metals and PI—calculated values for the Single Pollution Index.

Potential ecological risk $(R I)$ is used to estimate the degree of ecological risk associated with detrimental effects of trace metals [64]. The basic formula as follows:

$$
R I=\sum_{i=1}^{n} E_{r}^{i}
$$

where: $n$-the number of heavy metals and $E_{r}$-single index of the ecological risk factor calculated based on the formula:

$$
E_{r}^{i}=T_{r}^{i} \times P I
$$

where: $T_{r}$ - the toxicity response coefficient of an individual metal (Cd-30; $\mathrm{As}-10 ; \mathrm{Ni}, \mathrm{Pb}, \mathrm{Cu}-5$; Cr-2; Zn-1) [64] and PI-calculated values for the Single Pollution Index.

All of the applied indices have their own evaluation scales, which are shown in Table 2. 
Table 2. Evaluation scales of used indexes [60-62,64].

\begin{tabular}{|c|c|c|c|c|c|c|c|}
\hline \multicolumn{2}{|c|}{ Igeo } & \multicolumn{2}{|c|}{ PI } & \multicolumn{2}{|r|}{ PLI } & \multicolumn{2}{|r|}{ RI } \\
\hline Value & Soil Quality & Value & $\begin{array}{c}\text { Soil } \\
\text { Pollution }\end{array}$ & Value & Pollution Status & Value & $\begin{array}{c}\text { Potential } \\
\text { Ecological Risk }\end{array}$ \\
\hline Igeo $<0$ & Unpolluted & $\mathrm{PI}<1$ & Absent & $<1$ & $\begin{array}{c}\text { Denote } \\
\text { perfection }\end{array}$ & $<90$ & Low \\
\hline $0 \leq$ Igeo $\leq 1$ & $\begin{array}{l}\text { Unpolluted to } \\
\text { moderately } \\
\text { polluted }\end{array}$ & $1<\mathrm{PI}<2$ & Low & 1 & $\begin{array}{l}\text { Only baseline } \\
\text { levels of } \\
\text { pollution }\end{array}$ & 90-180 & Moderate \\
\hline $1 \leq$ Igeo $\leq 2$ & $\begin{array}{l}\text { Moderately } \\
\text { polluted }\end{array}$ & $2<\mathrm{PI}<3$ & Moderate & $>1$ & $\begin{array}{c}\text { Deterioration of } \\
\text { soil quality }\end{array}$ & $180-360$ & Strong \\
\hline $2 \leq$ Igeo $\leq 3$ & $\begin{array}{l}\text { Moderately to } \\
\text { highly polluted }\end{array}$ & $3<\mathrm{PI}<5$ & Strong & & & $360-720$ & Very strong \\
\hline $3 \leq$ Igeo $\leq 4$ & Highly polluted & $\mathrm{PI}>5$ & Very strong & & & $\geq 720$ & Highly-strong \\
\hline $4 \leq$ Igeo $\leq 5$ & $\begin{array}{c}\text { Highly to } \\
\text { extremely high } \\
\text { polluted }\end{array}$ & & & & & & \\
\hline Igeo $>5$ & $\begin{array}{l}\text { Extremely high } \\
\text { polluted }\end{array}$ & & & & & & \\
\hline
\end{tabular}

As background values of metal concentrations, the data given in publications $[65,66]$ were used. According to this information, the average values of metal concentrations are as follows: Pb-20; Cr-42; Cu-13; Cd-5; Ni-19; Zn-38; As-5 mg $\times$ kg $^{-1}$ [65,66].

Statsoft Statistica V12.0, GraphPad Prizm V9.0.0, and QGIS V3.16 software were used for visualization and statistical processing.

\section{Results}

\subsection{Key Soil Properties and Soil Diversity}

The main physico-chemical properties of the selected soil samples were determined (Table 3). All the studied soils are characterized by acidic reactions with $\mathrm{pH}$ values less than 7. This soil acidity is typical for the soils Yamal region, as humic climatic regimes dominate the region [67-70]. The lowest values of $\mathrm{pH}$ recorded in mature soils, if in the anthropogenic loaded soils acidity is characterized mainly as slightly acidic ( $\mathrm{pH} 5-7$ ), in mature soils marked by an acidity closer to acidic and strongly acidic ( $\mathrm{pH} 4-5)$. This difference may be due to processes of anthropogenic soil alkalization, which are noted in urban soils [71,72].

The content of total carbon (TOC) and nitrogen (TN) is highly differentiated within the soil profiles. All studied soil profiles are characterized by a high content of total carbon in the topsoil horizons. However, in some cases (profiles D and E), the highest TOC content was recorded in the deepest horizons. In the case of profile $\mathrm{D}$, the presence of a layer rich in carbon is explained by the past use of the soil for agricultural needs with its subsequent screening in the process of urbanization. For mature soil E, the accumulation of carbon occurs in the suprapermafrost depth horizon, permafrost prevents the leaching of organic particles and their accumulation occurs. In Figure 2 you can see the uppermost layer of accumulation in profile $\mathrm{E}$, a dark-colored horizon rich in organic matter is located above the permafrost surface. The situation is similar for $\mathrm{TN}$, with the highest content in the surface accumulative horizons. In isolated cases, there is a high content in the deep soil horizons (profiles D and E).

The soils of the Yamal region are highly variable in terms of total carbon and nitrogen content. The humus enrichment with nitrogen in the surface horizons of the studied soils is low $(\mathrm{C} / \mathrm{N}>10)$. The data we obtained are consistent with earlier studies in the territory of the Yamal and Gydan peninsulas, in the surface horizons of mature soils usually, the $\mathrm{C} / \mathrm{N}$ 
ratio does not fall below $10[28,69,73]$. Abandoned agricultural soils are also characterized by nitrogen deficiency in the surface soil horizons [70]. The level of basal respiration between anthropogenically loaded and mature soils differs significantly. Anthropogenic soils show a higher level of carbon dioxide emission compared to mature soils (especially in the topsoil horizons). The maximum values of basal respiration were recorded in the upper soil horizons with high carbon content (up to $32 \mathrm{mgCO}_{2} \times 100 \mathrm{~g}^{-1} \times 24 \mathrm{~h}^{-1}$ ). However, our data are slightly different from those previously published, for pristine and abandoned agricultural soils the basal respiration level reached $1084 \mathrm{mgCO}_{2} \times 100 \mathrm{~g}^{-1} \times 24 \mathrm{~h}^{-1}$, with values close to those we obtained about the carbon content [70]. The particle size distribution of anthropogenic-loaded soils differs significantly from that of mature soils. Anthropogenically loaded soils are distinguished by a larger share of the skeleton fraction (up to $25 \%$ ) in the sample and a lower percentage of the clay fraction in the fine-grained soil (up to $25 \%$ ). Mature soils are more clayey textured, up to $34 \%$ of clay particles in the fine-grained soil, and contain less skeletal fraction compared to anthropogenically loaded soils. Fractional composition is one of the main soil parameters, as it largely affects the processes of migration, transformation, and accumulation of organic matter [74-76], as well as regulating the thermal and water soil regime [77]. It is worth noting that in both anthropogenically loaded and mature soils, there is an increase in the proportion of clay fraction in the depth of the soil profile, indicating the presence of illuviation processes in the studied soils.

Table 3. Key soil properties.

\begin{tabular}{|c|c|c|c|c|c|c|c|c|c|c|}
\hline $\begin{array}{l}\text { Sample } \\
\text { Code }\end{array}$ & $\begin{array}{l}\text { Depth, } \\
\text { cm }\end{array}$ & Color & $\begin{array}{c}\text { TOC, \% } \\
\pm \text { SD }\end{array}$ & $\begin{array}{l}\text { TN, \% } \\
\pm \text { SD }\end{array}$ & $\mathrm{C} / \mathrm{N}$ & $\begin{array}{c}\mathrm{pH} \\
\mathrm{H}_{2} \mathrm{O}\end{array}$ & $\underset{\mathrm{CaCl}_{2}}{\mathrm{pH}}$ & $\begin{array}{c}\text { BR, } \\
\mathrm{mgCO}_{2} \times 100 \mathrm{~g}^{-1} \\
\times 24 \mathrm{~h}^{-1}\end{array}$ & $\begin{array}{c}\text { Skelet, } \\
\%\end{array}$ & $\begin{array}{c}\text { Clay, } \\
\%\end{array}$ \\
\hline \multicolumn{11}{|c|}{ Urbanized agricultural soils (anthropogenic loaded) } \\
\hline \multirow[b]{2}{*}{ A2 } & $0-2$ & $7 / 5$ YR 5/3 & $8.60 \pm 0.35$ & $0.64 \pm 0.04$ & 13 & 5.90 & 5.21 & 29.00 & 8 & 12 \\
\hline & $2-15$ & $5 Y 7 / 6$ & $4.23 \pm 0.12$ & $0.23 \pm 0.03$ & 18 & 6.00 & 5.23 & 30.00 & 12 & 15 \\
\hline \multirow{5}{*}{ B } & $0-10$ & 10 YR 3/3 & $3.09 \pm 0.45$ & $0.27 \pm 0.03$ & 11 & 6.10 & 5.23 & 30.00 & 7 & 7 \\
\hline & $27-41$ & $10 \mathrm{YR} 5 / 3$ & $0.05 \pm 0.01$ & $0.005 \pm 0.01$ & 10 & 6.00 & 5.54 & 30.00 & 12 & 7 \\
\hline & $44-54$ & $10 \mathrm{YR} 5 / 3$ & $1.59 \pm 0.12$ & $0.12 \pm 0.02$ & 13 & 6.10 & 5.41 & 14.00 & 15 & 8 \\
\hline & $54-76$ & $10 \mathrm{YR} 5 / 3$ & $0.22 \pm 0.03$ & $0.03 \pm 0.01$ & 7 & 5.90 & 5.10 & 14.00 & 18 & 9 \\
\hline & $76-120$ & $10 \mathrm{YR} 5 / 3$ & $0.01 \pm 0.05$ & nd & nd & 5.70 & 5.00 & 14.00 & 19 & 12 \\
\hline \multirow{4}{*}{$\mathrm{C}$} & $0-7$ & 7/5 YR 5/1 & $23.92 \pm 0.92$ & $1.19 \pm 0.04$ & 20 & 4.80 & 4.12 & 32.00 & 21 & 9 \\
\hline & $7-24$ & $5 \mathrm{YR} / 7 / 3$ & $0.09 \pm 0.01$ & $0.02 \pm 0.01$ & 5 & 4.90 & 4.25 & 27.00 & 20 & 9 \\
\hline & $24-54$ & 5YR 7/5 & $0.23 \pm 0.04$ & $0.04 \pm 0.01$ & 6 & 4.90 & 4.15 & 23.00 & 21 & 12 \\
\hline & $54-78$ & $5 Y R 7 / 4$ & $0.47 \pm 0.06$ & $0.04 \pm 0.01$ & 12 & 5.10 & 4.19 & 23.00 & 25 & 14 \\
\hline \multirow{3}{*}{$\mathrm{D}$} & $0-20$ & 7/5 YR 5/1 & $2.77 \pm 0.18$ & $0.15 \pm 0.03$ & 18 & 5.50 & 4.80 & 23.00 & 14 & 17 \\
\hline & $20-23$ & $5 \mathrm{YR} 6 / 6$ & $7.42 \pm 0.51$ & $0.54 \pm 0.05$ & 14 & 5.30 & 4.75 & 23.00 & 24 & 25 \\
\hline & $23-33$ & 7/5 YR 5/1 & $3.68 \pm 0.28$ & $0.30 \pm 0.04$ & 12 & 5.35 & 4.75 & 12.00 & 27 & 19 \\
\hline \multicolumn{11}{|c|}{ Mature soils } \\
\hline \multirow{3}{*}{ A1 } & $0-6$ & 7/5 YR 5/1 & $11.96 \pm 0.31$ & $0.46 \pm 0.04$ & 26 & 5.10 & 4.56 & 11.00 & 3 & 15 \\
\hline & $6-60$ & $7 / 5$ YR 7/6 & $0.17 \pm 0.02$ & $0.03 \pm 0.01$ & 6 & 5.00 & 4.54 & 10.00 & 3 & 17 \\
\hline & $60-130$ & $5 \mathrm{G} 5 / 1$ & $0.03 \pm 0.01$ & $0.005 \pm 0.01$ & 6 & 5.20 & 4.25 & 28.00 & 6 & 20 \\
\hline \multirow{5}{*}{$\mathrm{E}$} & $0-12$ & 7/5 YR 5/1 & $2.30 \pm 0.17$ & $0.20 \pm 0.03$ & 12 & 4.90 & 4.00 & 18.00 & 3 & 25 \\
\hline & $12-27$ & 6,5 Y $7 / 1$ & $0.77 \pm 0.06$ & $0.06 \pm 0.01$ & 13 & 5.50 & 3.80 & 18.00 & 4 & 26 \\
\hline & $27-34$ & $6,5 Y 7 / 1$ & $1.02 \pm 0.05$ & $0.07 \pm 0.02$ & 15 & 4.90 & 4.20 & 18.00 & 3 & 26 \\
\hline & $35-43$ & $6,5 Y 7 / 2$ & $11.52 \pm 0.65$ & $0.55 \pm 0.05$ & 21 & 4.50 & 3.90 & 19.00 & 3 & 28 \\
\hline & $45-70 \mathrm{PF}$ & $5 \mathrm{G} 5 / 1$ & $0.38 \pm 0.05$ & $0.04 \pm 0.01$ & 10 & 4.70 & 4.20 & 30.00 & 5 & 34 \\
\hline \multirow{3}{*}{ F } & $0-22$ & 10 YR 5/1 & $37.81 \pm 1.12$ & $1.37 \pm 0.21$ & 28 & 4.90 & 4.32 & 21.00 & 5 & 25 \\
\hline & $22-30$ & $5 \mathrm{G} \mathrm{5/2}$ & $20.16 \pm 0.87$ & $1.09 \pm 0.03$ & 18 & 4.70 & 4.21 & 14.00 & 5 & 29 \\
\hline & 30-35 & $5 G 5 / 2$ & $2.56 \pm 0.20$ & $0.17 \pm 0.03$ & 15 & 4.10 & 4.10 & 12.00 & 8 & 31 \\
\hline
\end{tabular}

Total organic carbon (TOC) and total nitrogen (TN) were determined in three replicates; BR—basal respiration; nd—no data. 

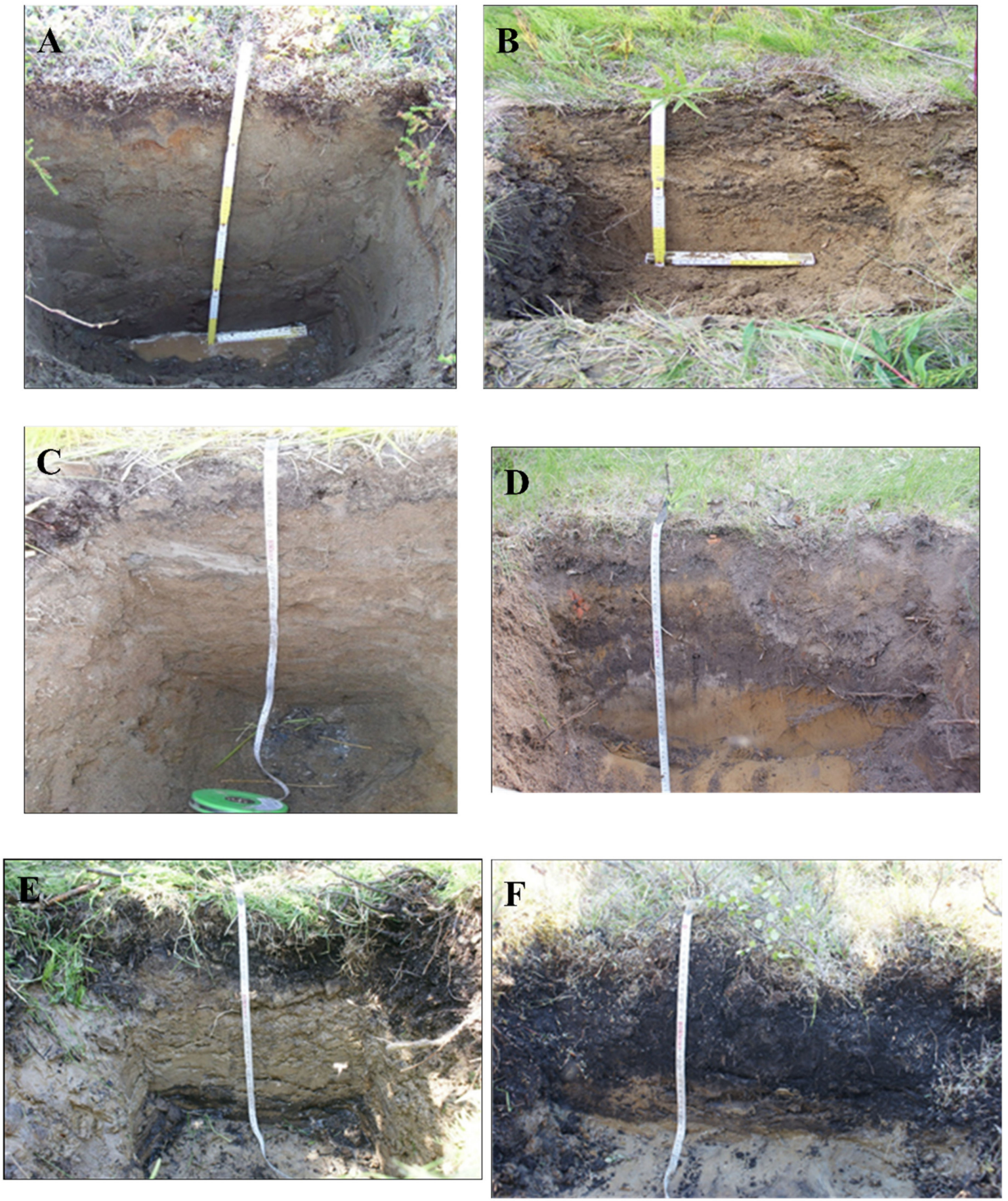

Figure 2. Soil diversity: (A,E,F)—mature soils; (B-D)—anthropogenically loaded soils.

\subsection{Agrochemical Properties}

The content of available forms of nutrients such as phosphorus, potassium, and nitrogen for plants is one of the key parameters of soil fertility $[78,79]$. These elements are crucial for driving of mineral nutrition system [80,81]. An understanding of the number of available nutrients in the soil allows you to plan agricultural activities and optimize land for certain types of crops to be planted [81,82]. In the natural environment available forms of phosphorus and nitrogen enter the soil together with organic matter in the 
process of humification and mineralization $[76,83]$, the source of potassium is most often aluminosilicate minerals [84]. Anthropogenic sources of nutrients most often are the processes of applying various mineral and organic fertilizers, which are applied to the arable soil horizons in the process of agriculture [53-55].

Laboratory analysis of soil samples showed that the content of major nutrients in mature and anthropogenically affected soils is significantly different. As can be seen in the graphs shown in Figure 3, the greatest difference is observed in the content of available forms of phosphorus and potassium between the two types of soils. The concentration of phosphorus in the surface horizons of anthropogenically loaded urbanized soils reaches $1750 \mathrm{mg} \times \mathrm{kg}^{-1}$, while in mature soils the maximum concentration of phosphorus does not exceed $200 \mathrm{mg} \times \mathrm{kg}^{-1}$. In some cases, there were recorded processes of accumulation of nutrients in suprapermafrost soil horizons. In particular, for $\mathrm{P}$ and $\mathrm{K}$, high concentrations of these elements are observed in mature soils A1 and E as compared with the middle horizons. The same phenomenon is observed in anthropogenically loaded soil C, the concentration of $\mathrm{P}$ and $\mathrm{K}$ in suprapermafrost horizons is higher than in the topsoil. Since in Arctic conditions the migration of nutrients through the soil profile is limited by permafrost, the accumulation of nutrients of mineral genesis in the lowest soil horizons is possible.

Differences in the content of available forms of nitrogen, both ammonium and nitrate, between the two types of soils studied are insignificant. In both cases, the maximum level of nitrogen is observed in the topsoil horizons.

Statistical processing of the data obtained showed significant differences in the content of available forms of phosphorus and potassium $(p<0.05)$ between mature and anthropogenically loaded soils (Table 4).

Table 4. Results of MANOVA analysis of nutrients content.

\begin{tabular}{|c|c|c|c|c|c|c|c|c|}
\hline \multirow{3}{*}{$\begin{array}{c}\text { Mature vs. } \\
\text { Anthropogenic } \\
\text { Soils }\end{array}$} & \multicolumn{2}{|c|}{$\begin{array}{c}\text { Available } \\
\text { phosphorous }(\mathrm{P})\end{array}$} & \multicolumn{2}{|c|}{$\begin{array}{c}\text { Available } \\
\text { potassium (K) }\end{array}$} & \multicolumn{2}{|c|}{$\begin{array}{c}\text { Ammonium } \\
\text { Nitrogen }\left(\mathrm{NH}_{4}\right)\end{array}$} & \multicolumn{2}{|c|}{$\begin{array}{c}\text { Nitrate } \\
\text { Nitrogen }\left(\mathrm{NO}_{3}\right)\end{array}$} \\
\hline & $\mathrm{F}$ & $p$ & $\mathrm{~F}$ & $p$ & $\mathrm{~F}$ & $p$ & $\mathrm{~F}$ & $p$ \\
\hline & 6.85 & 0.02 & 4.14 & 0.05 & 0.10 & 0.75 & 0.12 & 0.74 \\
\hline
\end{tabular}

The abandoned agricultural soils of the Arctic region are characterized by a high content of available forms of phosphorus and potassium [28,70]. Previously published data show that the features of temperature and water soil regimes contribute to the preservation of nutrients for a long time, especially in the topsoil horizons. The high content of available forms of phosphorus (up to $783 \mathrm{mg} \times \mathrm{kg}^{-1}$ ), potassium (up to $995 \mathrm{mg} \times \mathrm{kg}^{-1}$ ), and nitrogen (up to $57 \mathrm{mg} \times \mathrm{kg}^{-1}$ ) was recorded in the vicinity of Salekhard [28,70]. Soils in other countries that practice polar farming have somewhat lower nutrient contents, according to published data. For example, in the Norwegian province of Tromso, the maximum concentration of potassium does not exceed $66 \mathrm{mg} \times \mathrm{kg}^{-1}$ and phosphorus $12 \mathrm{mg} \times \mathrm{kg}^{-1}$ [85]. In actively used agricultural soils in Norway, the content of organic phosphorus reaches $670 \mathrm{mg} \times \mathrm{kg}^{-1}$ [86]. Comparing these data, it is evident that urbanized agricultural soils contain a very high concentration of nutrients, and taking them out of agricultural use is a loss in terms of soil resource deficit in the far north. 


\section{Mature soils}

\section{A1 \\ Conc. $\mathrm{mg} \times \mathrm{kg}^{-1}$}
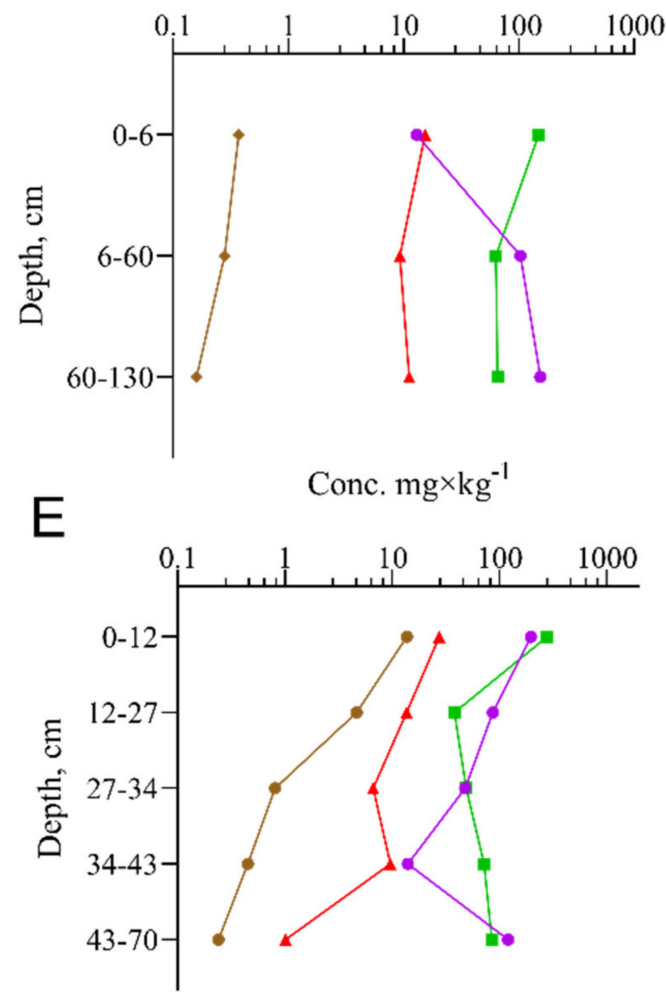

F

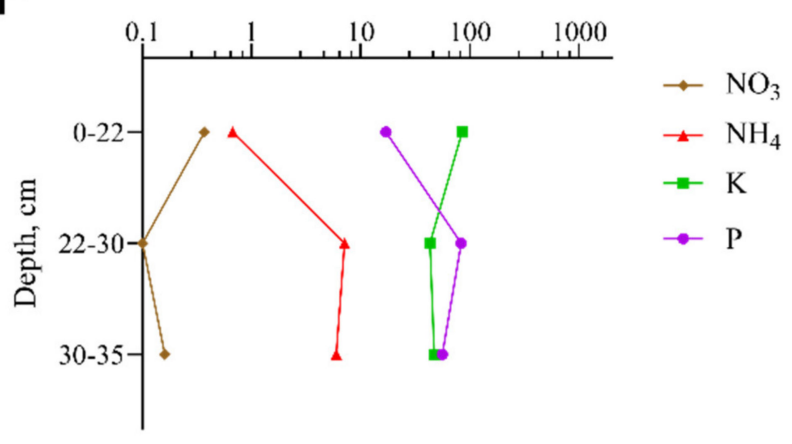

\begin{tabular}{ccccc} 
& $\mathrm{P}$ & $\mathrm{K}$ & $\mathrm{NH}_{4}$ & $\mathrm{NO}_{3}$ \\
\hline \multicolumn{5}{c}{ Mature Soils } \\
\hline Mean & 75.33 & 93.42 & 10.27 & 1.80 \\
\hline Max & 197.00 & 278.00 & 27.52 & 13.70 \\
\hline Min & 13.00 & 38.00 & 0.67 & 0.08 \\
\hline SD & 59.67 & 69.89 & 7.44 & 4.12 \\
\hline \multicolumn{5}{c}{ Anthropogenic Loaded Soils } \\
\hline Mcan & 605.62 & 246.38 & 9.75 & 2.15 \\
\hline Max & 1742.00 & 707.00 & 27.65 & 10.53 \\
\hline Min & 20.00 & 67.00 & 4.23 & 0.20 \\
\hline SD & 575.37 & 190.03 & 6.72 & 2.84 \\
\hline
\end{tabular}

\section{Anthropogenic soils}

A2 Conc. $\mathrm{mg} \times \mathrm{kg}^{-1}$

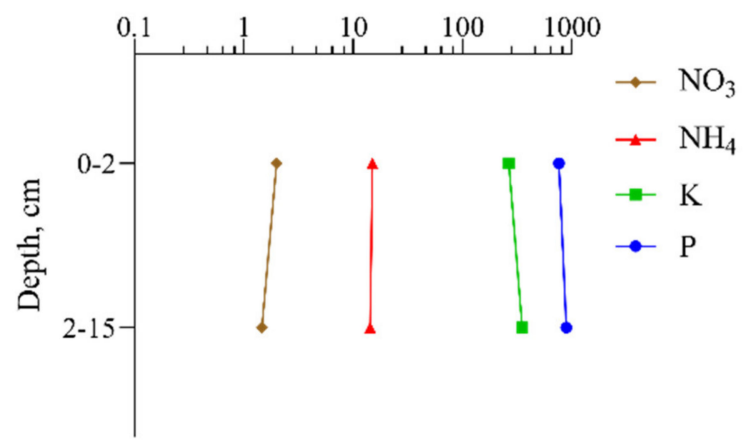

\footnotetext{
B

Conc. $\mathrm{mg} \times \mathrm{kg}^{-1}$
}

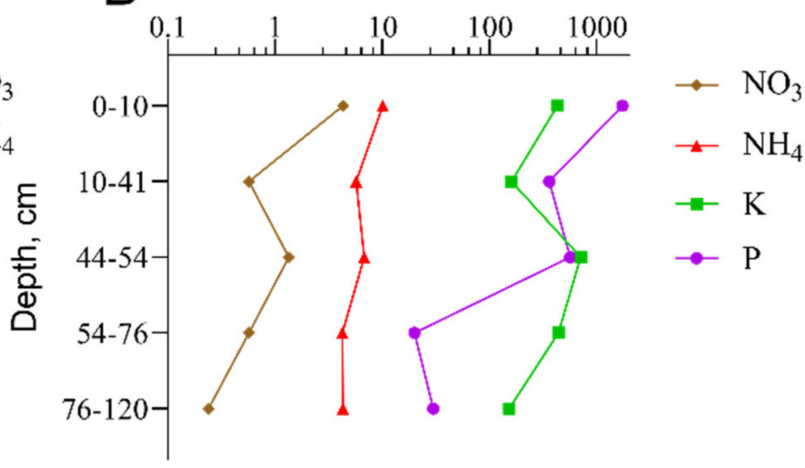

C Conc. $\mathrm{mg} \times \mathrm{kg}^{-1}$
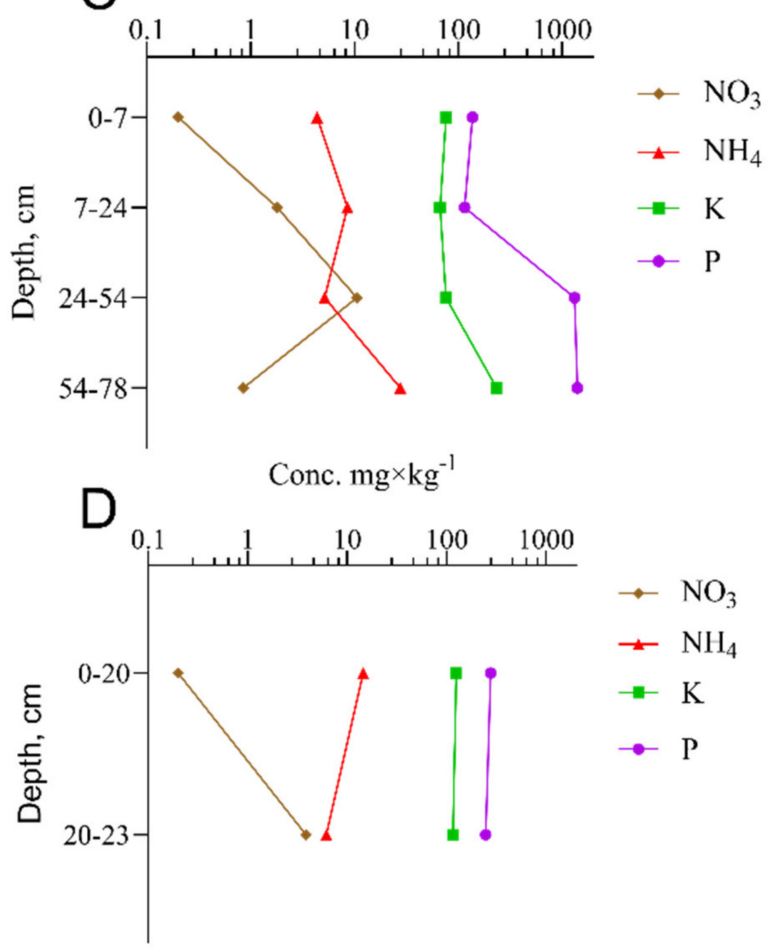

Figure 3. Distribution of nutrients in soil profiles and basic statistics: (A1,E,F)—mature soils; (A2,B,C,D)—anthropogenic loaded soils. 


\subsection{Pollution Status}

Soil cover is one of the most vulnerable natural converts and is highly susceptible to change under the influence of external factors, such as urbanization. Due to its sorption properties, soil actively accumulates products of anthropogenic activity and can act as an indicator of the degree of anthropogenic load [87-89]. One of the main agents of anthropogenic pressure and urbanization is the input of trace metals such as $\mathrm{Pb}, \mathrm{Cr}, \mathrm{Cd}$, As, and some others into the environment $[57,90]$. Trace metals enter the environment through various industrial processes, the combustion of fossil fuels, and from power plant emissions [91,92]. The detrimental effects of trace metals on human health have been well understood, they have carcinogenic and mutagenic properties, and they strongly affect the productivity of agricultural crops $[58,59,93]$. One of the sources of trace metals in the soils of cities in the Arctic region is the consequences of the accumulation of industrial, especially toxic waste $[94,95]$.

In our study, the differentiation of trace metals content between mature and anthropogenic soils is slightly different. As can be seen in Figure 4, the maximum concentration among metals is observed for $\mathrm{Zn}\left(117 \mathrm{mg} \times \mathrm{kg}^{-1}\right.$ in anthropogenic loaded soils; $73 \mathrm{mg} \times \mathrm{kg}^{-1}$ in mature soils). The minimum concentration among all metals studied was recorded for $\mathrm{Cd}$, in most cases, its concentration was below the detection limit, the maximum values were recorded in urbanized agricultural soils $\left(0.595 \mathrm{mg} \times \mathrm{kg}^{-1}\right)$, and the minimum in mature soils $\left(0.005 \mathrm{mg} \times \mathrm{kg}^{-1}\right)$.

The vertical distribution of trace metals concentrations across soil profiles is heterogeneous; for urbanized soils, trends in decreasing concentrations with depth are mainly traceable. For mature soils, the situation is reversed, in general, the content of metals increases at the depth of the soil profile, it may be associated with the sorption capacity of clay particles [96-98], the increase in the content of which with depth was noted earlier (Table 3).

No significant differences $(p<0.05)$ in concentrations between the two soil types were found in the statistical analysis (Table 5). However, the lowest $p$-values were found for $\mathrm{Pb}$ and $\mathrm{Cd}(0.18$ and 0.23 , respectively). Some researchers have noted an increased intake of exactly these elements in the urban environment compared to the natural $[99,100]$.

Table 5. Results of MANOVA analysis for trace metals content.

\begin{tabular}{|c|c|c|c|c|c|c|c|c|c|c|c|c|c|c|}
\hline \multirow{3}{*}{$\begin{array}{l}\text { Mature vs. } \\
\text { Anthropogenic } \\
\text { Soils }\end{array}$} & \multicolumn{2}{|c|}{$\mathrm{Pb}$} & \multicolumn{2}{|c|}{$\mathrm{Cr}$} & \multicolumn{2}{|c|}{$\mathrm{Cu}$} & \multicolumn{2}{|c|}{$\mathrm{Cd}$} & \multicolumn{2}{|c|}{$\mathrm{Zn}$} & \multicolumn{2}{|c|}{ As } & \multicolumn{2}{|c|}{$\mathrm{Ni}$} \\
\hline & $\mathrm{F}$ & $p$ & $\mathrm{~F}$ & $p$ & $\mathrm{~F}$ & $p$ & $\mathrm{~F}$ & $p$ & $\mathrm{~F}$ & $p$ & $\mathrm{~F}$ & $p$ & $\mathrm{~F}$ & $p$ \\
\hline & 1.88 & 0.18 & 0.02 & 0.90 & 0.28 & 0.60 & 1.50 & 0.23 & 0.83 & 0.37 & 0.09 & 0.77 & 0.26 & 0.62 \\
\hline
\end{tabular}

The content of trace metals in pristine soils of the Yamal-Nenets Autonomous District is highly differentiated, with the concentrations of $\mathrm{Zn}, \mathrm{Pb}$, and $\mathrm{Cr}$ showing the greatest variability in trace metals concentrations. According to published data, the $\mathrm{Zn}$ content in pristine soils of the Gydan Peninsula varies from 31 to $92 \mathrm{mg} \times \mathrm{kg}^{-1}, \mathrm{~Pb}$ content from 4 to $14 \mathrm{mg} \times \mathrm{kg}^{-1}$ [69]. The researcher recorded $\mathrm{Cr}$ concentrations equal to $23.5 \mathrm{mg} \times \mathrm{kg}^{-1}$ on Belyi Island, and $3.1 \mathrm{mg} \times \mathrm{kg}^{-1}$ in the vicinity of the village of Yar-Sale [66,101]. Trace metal concentrations in the soils of urbanized areas of YANAO depend largely on the degree of anthropogenic pressure in individual cases [102]. Previously published data on the content of metals in the soils of Salekhard indicate average concentrations of $\mathrm{Pb}$ $7.2 \mathrm{mg} \times \mathrm{kg}^{-1}, \mathrm{Cu} 6.5 \mathrm{mg} \times \mathrm{kg}^{-1}$, and As $3 \mathrm{mg} \times \mathrm{kg}^{-1}$ [68]. In the larger city of Novy Urengoy, the concentration of $\mathrm{Pb}$ in urban soils is $10 \mathrm{mg} \times \mathrm{kg}^{-1}, \mathrm{Cr} 18 \mathrm{mg} \times \mathrm{kg}^{-1}, \mathrm{Cu}$ $9 \mathrm{mg} \times \mathrm{kg}^{-1}$, and Zn $32 \mathrm{mg} \times \mathrm{kg}^{-1}$ [101]. Comparing these data with the results obtained in our study, we can say that our data in some cases exceed the previously published concentrations for both pristine and anthropogenically loaded soils. 


\section{Mature soils \\ A1 \\ Conc. $\mathrm{mg} \times \mathrm{kg}^{-1}$}

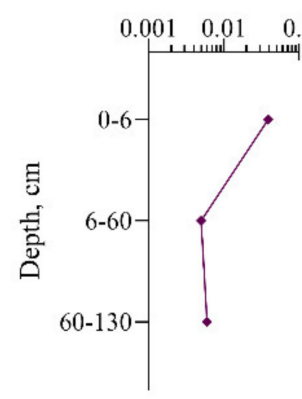

$10 \longrightarrow \mathrm{Pb}$

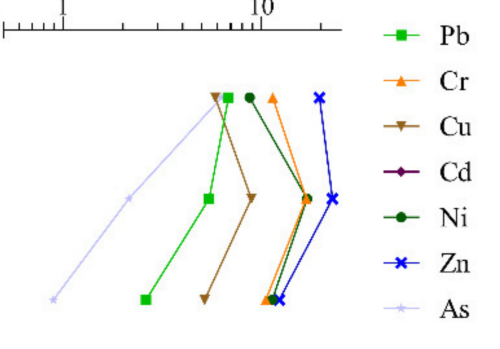

E

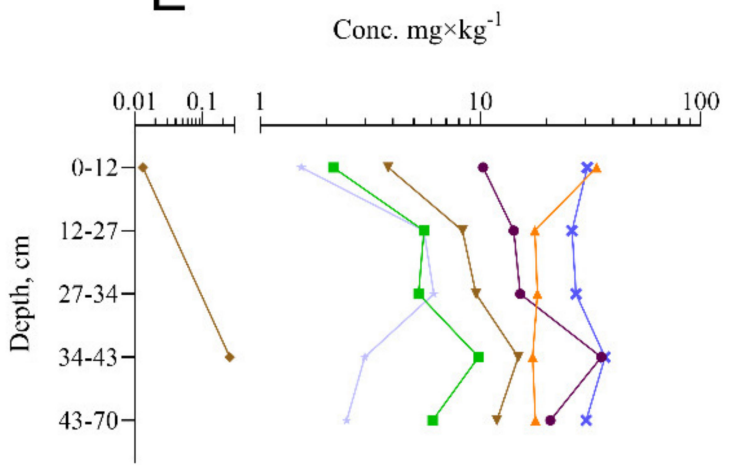

F

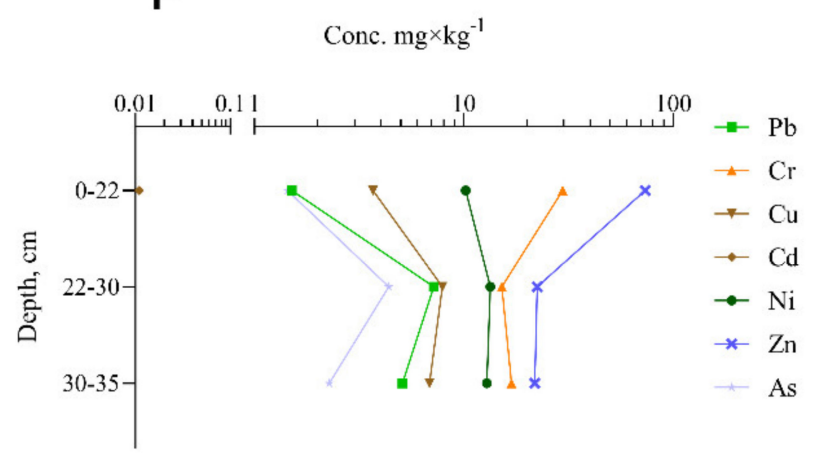

\begin{tabular}{cccccccc} 
& $\mathrm{Pb}$ & $\mathrm{Cr}$ & $\mathrm{Cu}$ & $\mathrm{Cd}$ & $\mathrm{Ni}$ & $\mathrm{Zn}$ & $\mathrm{As}$ \\
\hline \multicolumn{7}{c}{ Mature Soils } \\
\hline Mean & 5.23 & 18.66 & 7.89 & 0.05 & 15.41 & 29.40 & 3.28 \\
\hline Max & 9.83 & 33.80 & 14.90 & 0.25 & 35.50 & 73.40 & 6.28 \\
\hline Min & 1.51 & 10.50 & 3.68 & 0.01 & 8.72 & 12.30 & 0.89 \\
\hline SD & 2.42 & 7.02 & 3.41 & 0.10 & 7.50 & 15.97 & 1.97 \\
\hline \multicolumn{7}{c}{ Anthropogenic Loaded Soils } \\
\hline Mean & 10.56 & 13.80 & 7.90 & 0.19 & 9.59 & 37.48 & 2.23 \\
\hline Max & 40.50 & 30.70 & 11.80 & 0.14 & 12.80 & 63.40 & 5.51 \\
\hline Min & 0.27 & 4.66 & 1.93 & 0.05 & 4.12 & 5.80 & 0.87 \\
\hline SD & 14.07 & 11.31 & 4.60 & 0.20 & 4.15 & 35.80 & 1.59 \\
\hline \multicolumn{7}{c}{}
\end{tabular}

\section{Anthropogenic soils \\ Conc. $\mathrm{mg} \times \mathrm{kg}^{-1}$}

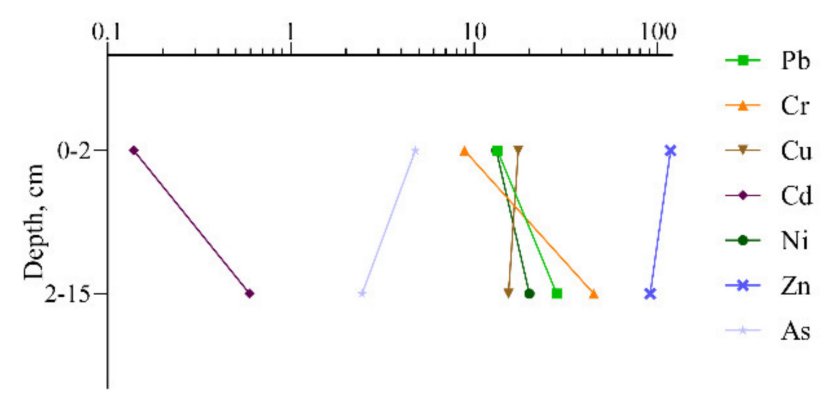

B

Conc. $\mathrm{mg} \times \mathrm{kg}^{-1}$

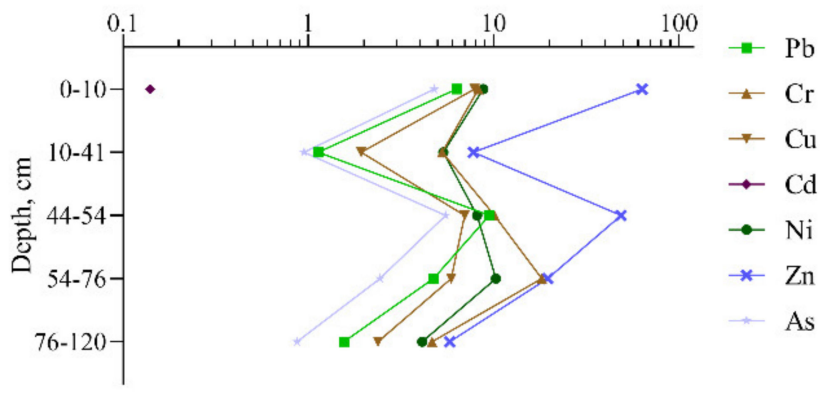

C
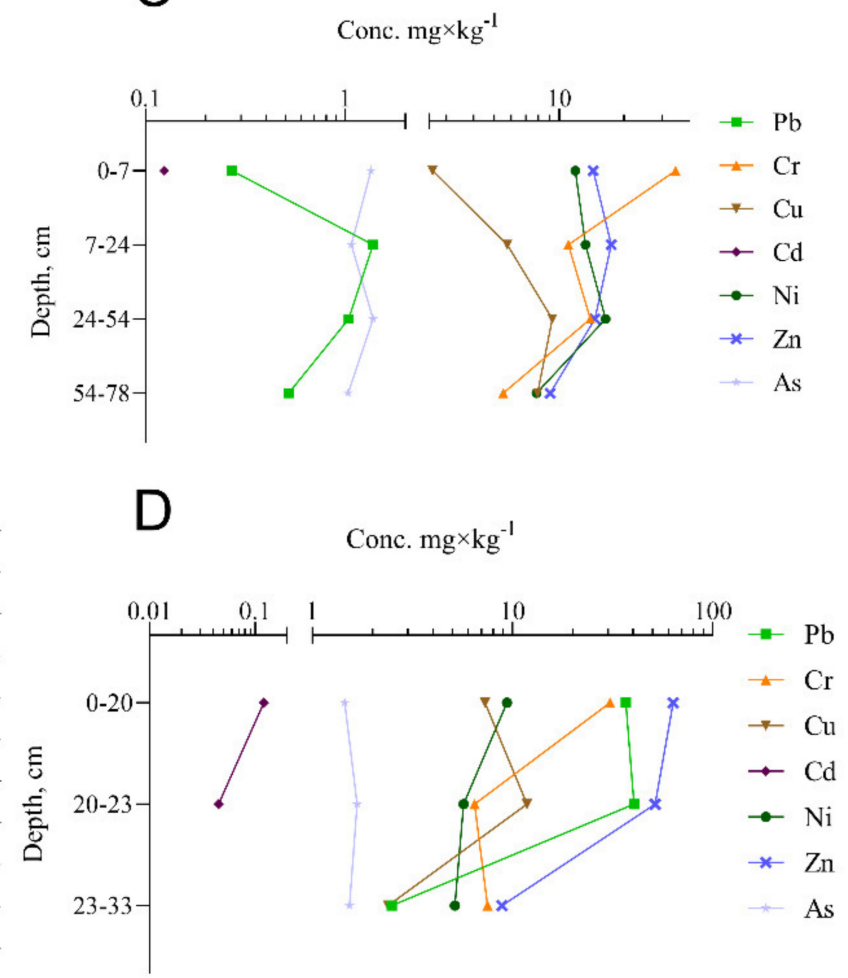

Figure 4. Distribution of trace metals in soil profiles and basic statistics: (A1,E,F)—mature soils; (A2,B,C,D)—anthropogenic loaded soils. 
To qualitatively assess soil trace metal contamination, several individual and complex indices were applied. As background values of metal concentrations, the data given in publications $[65,66]$ were used. Average values of metal concentrations are as follows: $\mathrm{Pb}$ 20; Cr 42; Cu 13; Cd 5; Ni 19; Zn 38; As 5 mg $\times \mathrm{kg}^{-1}[65,66]$.

According to the results of the calculation of the geoaccumulation index Igeo, the studied soils are estimated as unpolluted by the content of most metals (Table 6). In rare cases, contamination of the topsoil horizons of urbanized soils was detected at point A2, here the contamination of $\mathrm{Zn}$ is rated as Unpolluted to moderately polluted.

Table 6. Igeo index values for each soil horizon.

\begin{tabular}{|c|c|c|c|c|c|c|c|c|}
\hline Sample Code & Depth, cm & $\mathbf{P b}$ & $\mathrm{Cr}$ & $\mathrm{Cu}$ & $\mathrm{Cd}$ & $\mathbf{N i}$ & $\mathrm{Zn}$ & As \\
\hline \multicolumn{9}{|c|}{ Urbanized agricultural soils (anthropogenic loaded) } \\
\hline \multirow{2}{*}{ A2 } & $0-2$ & 0 & 0 & 0 & -4 & -1 & 1 & -2 \\
\hline & $2-15$ & -1 & -3 & 0 & -6 & -1 & 1 & -1 \\
\hline \multirow{5}{*}{ B } & $0-10$ & -2 & -3 & -1 & -6 & -2 & 0 & -1 \\
\hline & $27-41$ & -5 & -4 & -3 & nd & -2 & -3 & -3 \\
\hline & $44-54$ & -2 & -3 & -1 & nd & -2 & 0 & 0 \\
\hline & $54-76$ & -3 & -2 & -2 & nd & -1 & -2 & -2 \\
\hline & $76-120$ & -4 & -4 & -3 & nd & -3 & -3 & -3 \\
\hline \multirow{4}{*}{$\mathrm{C}$} & $0-7$ & -7 & -2 & -2 & -6 & -1 & -2 & -2 \\
\hline & $7-24$ & -4 & -3 & -1 & nd & -1 & -2 & -3 \\
\hline & $24-54$ & -5 & -2 & -1 & nd & -1 & -2 & -2 \\
\hline & 54-78 & -6 & -3 & -1 & nd & -2 & -3 & -3 \\
\hline \multirow{3}{*}{$\mathrm{D}$} & $0-20$ & 0 & -1 & -1 & -6 & -2 & 0 & -2 \\
\hline & $20-23$ & 0 & -3 & -1 & -7 & -2 & 0 & -2 \\
\hline & $23-33$ & -4 & -3 & -3 & nd & -2 & -3 & -2 \\
\hline \multicolumn{9}{|c|}{ Mature soils } \\
\hline \multirow{3}{*}{ A1 } & $0-6$ & -2 & -2 & -2 & -8 & -2 & -2 & 0 \\
\hline & $6-60$ & -2 & -2 & -1 & -11 & -1 & -1 & -2 \\
\hline & 60-130 & -4 & -3 & -2 & -10 & -1 & -2 & -3 \\
\hline \multirow{5}{*}{ E } & $0-12$ & -4 & -1 & -2 & -9 & -1 & -1 & -2 \\
\hline & $12-27$ & -2 & -2 & -1 & nd & -1 & -1 & 0 \\
\hline & $27-34$ & -3 & -2 & -1 & nd & -1 & -1 & 0 \\
\hline & $35-43$ & -2 & -2 & 0 & -5 & 0 & -1 & -1 \\
\hline & $45-70 \mathrm{PF}$ & -2 & -2 & -1 & nd & 0 & -1 & -2 \\
\hline \multirow{3}{*}{$\mathrm{F}$} & $0-22$ & -4 & -1 & -2 & -9 & -1 & 0 & -2 \\
\hline & $22-30$ & -2 & -2 & -1 & nd & -1 & -1 & -1 \\
\hline & $30-35$ & -3 & -2 & -2 & nd & -1 & -1 & -2 \\
\hline
\end{tabular}

Using the PI index gave slightly different results compared to Igeo. In most cases, the level of metal contamination is estimated as absent but found a low level of As contamination (Table 7), in the topsoil horizons of soil A2 Zn contamination, is estimated as moderate. For this soil, a low level of contamination of $\mathrm{Pb}, \mathrm{Cr}$, and $\mathrm{Cu}$ was recorded.

Application of complex indices PLI and RI showed that the total pollution of soils by trace metals is insignificant, despite the processes of urbanization the condition of soils can be assessed as uncontaminated or background. The level of potential environmental risk (RI) is estimated as low for all the studied soils. 
Table 7. PI, RI, and PLI indices values for each soil horizon.

\begin{tabular}{|c|c|c|c|c|c|c|c|c|c|c|}
\hline \multirow{2}{*}{ Sample Code } & \multirow{2}{*}{ Depth, cm } & \multicolumn{7}{|c|}{ PI } & \multirow{2}{*}{ RI } & \multirow{2}{*}{ PLI } \\
\hline & & $\mathbf{P b}$ & $\mathrm{Cr}$ & $\mathrm{Cu}$ & $\mathrm{Cd}$ & $\mathrm{Ni}$ & $\mathrm{Zn}$ & As & & \\
\hline \multicolumn{11}{|c|}{ Urbanized agricultural soils (anthropogenic loaded) } \\
\hline \multirow{2}{*}{$\mathrm{A} 2$} & $0-2$ & 1.4 & 1.1 & 1.2 & 0.1 & 1.1 & 2.4 & 0.5 & 31 & 0 \\
\hline & $2-15$ & 0.7 & 0.2 & 1.3 & 0.0 & 0.7 & 3.1 & 1.0 & 27 & 0 \\
\hline \multirow{5}{*}{ B } & $0-10$ & 0.3 & 0.2 & 0.6 & 0.0 & 0.5 & 1.7 & 1.0 & 19 & 0 \\
\hline & $27-41$ & 0.1 & 0.1 & 0.1 & 0.0 & 0.3 & 0.2 & 0.2 & 5 & 0 \\
\hline & $44-54$ & 0.5 & 0.2 & 0.5 & nd & 0.4 & 1.3 & 1.1 & 20 & 0 \\
\hline & $54-76$ & 0.2 & 0.4 & 0.5 & nd & 0.5 & 0.5 & 0.5 & 12 & 0 \\
\hline & $76-120$ & 0.1 & 0.1 & 0.2 & nd & 0.2 & 0.2 & 0.2 & 5 & 0 \\
\hline \multirow{4}{*}{$\mathrm{C}$} & $0-7$ & 0.0 & 0.4 & 0.4 & 0.0 & 0.6 & 0.3 & 0.3 & 10 & 0 \\
\hline & $7-24$ & 0.1 & 0.3 & 0.6 & nd & 0.6 & 0.3 & 0.2 & 9 & 0 \\
\hline & $24-54$ & 0.1 & 0.3 & 0.7 & nd & 0.7 & 0.3 & 0.3 & 11 & 0 \\
\hline & $54-78$ & 0.0 & 0.2 & 0.7 & nd & 0.5 & 0.3 & 0.2 & 9 & 0 \\
\hline \multirow{3}{*}{$\mathrm{D}$} & $0-20$ & 1.8 & 0.7 & 0.6 & 0.0 & 0.5 & 1.7 & 0.3 & 21 & 0 \\
\hline & $20-23$ & 2.0 & 0.2 & 0.9 & 0.0 & 0.3 & 1.4 & 0.3 & 21 & 0 \\
\hline & $23-33$ & 0.1 & 0.2 & 0.2 & nd & 0.3 & 0.2 & 0.3 & 7 & 0 \\
\hline \multicolumn{11}{|c|}{ Mature soils } \\
\hline \multirow{3}{*}{ A1 } & $0-6$ & 0.3 & 0.3 & 0.4 & 0.0 & 0.5 & 0.5 & 1.3 & 20 & 0 \\
\hline & $6-60$ & 0.3 & 0.4 & 0.7 & 0.0 & 0.9 & 0.6 & 0.4 & 15 & 0 \\
\hline & 60-130 & 0.1 & 0.3 & 0.4 & 0.0 & 0.6 & 0.3 & 0.2 & 8 & 0 \\
\hline \multirow{5}{*}{$\mathrm{E}$} & $0-12$ & 0.1 & 0.8 & 0.3 & -9 & 0.5 & 0.8 & 0.3 & 10 & 0 \\
\hline & $12-27$ & 0.3 & 0.4 & 0.6 & nd & 0.7 & 0.7 & 1.1 & 21 & 0 \\
\hline & $27-34$ & 0.3 & 0.4 & 0.7 & nd & 0.8 & 0.7 & 1.2 & 23 & 0 \\
\hline & $35-43$ & 0.5 & 0.4 & 1.1 & 0.1 & 1.9 & 1.0 & 0.6 & 27 & 0 \\
\hline & $45-70 \mathrm{PF}$ & 0.3 & 0.4 & 0.9 & nd & 1.1 & 0.8 & 0.5 & 18 & 0 \\
\hline \multirow{3}{*}{ F } & $0-22$ & 0.1 & 0.7 & 0.3 & 0.0 & 0.5 & 1.9 & 0.3 & 11 & 0 \\
\hline & $22-30$ & 0.4 & 0.4 & 0.6 & nd & 0.7 & 0.6 & 0.9 & 18 & 0 \\
\hline & $30-35$ & 0.3 & 0.4 & 0.5 & nd & 0.7 & 0.6 & 0.5 & 13 & 0 \\
\hline
\end{tabular}

nd-no data.

\section{Conclusions}

As a result of the work conducted, we can summarize that the process of urbanization of the Arctic regions has affected the soils suitable for agriculture. In conditions of lack of soil resources, this fact is especially important, because these areas could be used in agriculture, which would certainly play a role in ensuring food security of the Arctic regions in the framework of achieving the goals of sustainable development. From our point of view, the planning of urban development, especially in the Arctic region, should be guided by the principles of maximum conservation of biodiversity and soil resources. Since the sustainable development of the northern regions largely depends on the food supply, and soil resources suitable for agriculture play a fundamental role in this.

The studied urbanized agricultural soils are highly different from the mature soils of the Yamal-Nenets Autonomous District. There are differences in the $\mathrm{C} / \mathrm{N}$ ratio in the topsoil horizons of urbanized soils, it is somewhat lower compared with the background, indicating a less deficiency of nitrogen in the soil profile. Processes of anthropogenic alkalization of soils are observed, as evidenced by the difference in $\mathrm{pH}$ values between the studied soils. Urbanized agricultural soils are fundamentally different from the background (mature) soils of the region in terms of nutrient content. The content of available forms of phosphorus and potassium is significantly higher in former agricultural soils compared with background (mature) soils. This can be explained by the past fertilization of the soil, the effect of which has remained despite the urbanization of the areas. Statistical 
processing of the data obtained showed that the main difference in the content of nutrients is significant $(p<0.05)$ for the content of phosphorus and potassium in the studied soils.

The studied soils, both mature and urbanized soils are not contaminated with trace metals, which was proved by the application of various individual and complex soil ecotoxicological integrative indices. The potential environmental risk for all soils (including urbanized soils) is evaluated as low, which indicates the good toxicological state of the soils and their suitability for agriculture at present.

Author Contributions: Conceptualization E.A. and T.N., methodology E.A., T.N. and E.M., fieldwork R.L., R.K. and E.M., supervision E.A. and E.M. All authors have read and agreed to the published version of the manuscript.

Funding: This work was supported by Russian Foundation for Basic Research, project No 19-416890002 p-a.

Institutional Review Board Statement: Not applicable.

Informed Consent Statement: Not applicable.

Data Availability Statement: The data that support the findings of this study are available from the corresponding author, upon reasonable request.

Acknowledgments: Authors thank the Department of Science and Innovation of Yamal region and for Arctic Research Center of the Yamal-Nenets Autonomous District for their logistical and other support of our research. Some soil routine analyses were performed in the Research park of SaintPetersburg State University, Research Center "Chemical analyses and Materials research center".

Conflicts of Interest: The authors declare no conflict of interest.

\section{References}

1. Assembly, G. Resolution adopted by the General Assembly on 19 September 2016; A/RES/71/1, 3 October 2016 (The New York Declaration): 2015. Available online: https://www.un.org/en/development/desa/population/migration/generalassembly/ docs/globalcompact/A_RES_71_1.pdf (accessed on 29 May 2021).

2. Dokuchaev, V.V. Russian Chernozem; Jerusalem (Israel) IPST: Jerusalem, Israel, 1967; Volume 1, p. 376.

3. Vernadsky, V. Living matter. Sel. Sci. Work. Acad. Vernadsky 1978, 1, 358. (In Russian)

4. Vernadsky, V.I. The Biosphere; Springer: Berlin/Heidelberg, Germany, 1998.

5. Vernadsky, V.I. Biosfera i Noosfera. Available online: https://monoskop.org/File:Vernadsky_Vladimir_Biosfera_i_noosfera_1989 .pdf (accessed on 28 May 2021). (In Russian).

6. Dokuchaev, V. Izbrannye Sochineniya; Ogiz: Moscow, Russia, 1947; Volume 1, pp. 47-476. (In Russian)

7. Dobrovolsky, G.V.; Kust, G.S.; Sanaev, V.G. The Soils in the Biosphere and in Human Life: A Monograph; Moscow State Forest University: Moscow, Russia, 2012; p. 584. Available online: лные\%20тексты/Почвы\%20в\%20биосфере\%20и\%20жизни\%20человека.pdf (accessed on 25 May 2021). (In Russian)

8. Rodríguez-Eugenio, N.; McLaughlin, M.; Pennock, D. Soil Pollution: A Hidden Reality; FAO: Rome, Italy, $2018 ;$ p. 142.

9. Food and Agriculture Organization (FAO). Status of the World's Soil Resources (SWSR)—Main Report; Food and Agriculture Organization of the United Nations and Intergovernmental Technical Panel on Soils: Rome, Italy, 2015; p. 650. Available online: http:/ / www.fao.org/documents/card/ru/c/c6814873-efc3-41db-b7d3-2081a10ede50/ (accessed on 1 June 2021).

10. Kovda, V.A. Soils pathology and planet's biosphere safe. Biosfera 2011, 3, 4.

11. Litvin, L.F.; Kiryukhina, Z.P.; Krasnov, S.F.; Dobrovol'Skaya, N.G. Dynamics of agricultural soil erosion in European Russia. Eurasian Soil Sci. 2017, 50, 1344-1353. [CrossRef]

12. Bridges, E.M.; Oldeman, L.R. Global assessment of human-induced soil degradation. Arid. Soil Res. Rehabil. 1999, 13, 319-325. [CrossRef]

13. Toy, T.J.; Foster, G.R.; Renard, K.G. Soil Erosion: Processes, Prediction, Measurement and Control; John Wiley and Sons: Hoboken, NJ, USA, 2002.

14. Morgan, R.P.C. Soil Erosion and Conservation; John Wiley and Sons: Hoboken, NJ, USA, 2009.

15. Litvin, L. Soil erosion on agricultural lands in Russia. Eurasian Soil Sci. 1997, 30, 517-523.

16. Arunakumara, K.K.I.U.; Walpola, B.C.; Yoon, M.-H. Current status of heavy metal contamination in Asia's rice lands. Rev. Environ. Sci. Bio. Technol. 2013, 12, 355-377. [CrossRef]

17. Maliszewska-Kordybach, B. Polycyclic aromatic hydrocarbons in agricultural soils in Poland: Preliminary proposals for criteria to evaluate the level of soil contamination. Appl. Geochem. 1996, 11, 121-127. [CrossRef]

18. Burdukovskii, M.; Golov, V.I.; Kovshik, I.G. Changes in the agrochemical properties of major arable soils in the south of the Far East of Russia under the impact of their long-term agricultural use. Eurasian Soil Sci. 2016, 49, 1174-1179. [CrossRef] 
19. Blume, H.-P. Classification of soils in urban agglomerations. Catena 1989, 16, 269-275. [CrossRef]

20. Greinert, A. Functions of soils in the urban environment. Soils within cities. In Global Approaches to Their Sustainable Management; Schweizerbat Science Publishers: Stuttgart, Germany, 2017; pp. 43-52.

21. Marcotullio, P.J.; Braimoh, A.K.; Onishi, T. The impact of urbanization on soils. In Land Use and Soil Resources; Springer: Berlin/Heidelberg, Germany, 2008; pp. 201-250.

22. Asabere, S.B.; Zeppenfeld, T.; Nketia, K.A.; Sauer, D. urbanization leads to increases in $\mathrm{pH}$, carbonate, and soil organic matter stocks of arable soils of Kumasi, Ghana (West Africa). Front. Environ. Sci. 2018, 6, 119. [CrossRef]

23. Dybbroe, S.; Dahl, J.; Muller-Wille, L. Dynamics of Arctic urbanization. Acta Boreal. 2010, 27, 120-124. [CrossRef]

24. Pilyasov, A.N. Russia's Arctic frontier: Paradoxes of development. Reg. Res. Russ. 2016, 6, 227-239. [CrossRef]

25. Abakumov, E.V.; Koptseva, E.M.; Morgun, E.N. Urbanization in the Arctic: Status and trends. Sci. Bull. Yamalo-Nenets Auton. Dist. 2018, 3, 55-60. (In Russian)

26. Rosstat. Ofitsial'naya Statistika/Naselenie/Uroven'Zhizni [Official Statistical Data/Population/Quality of Life]. Retrieved 19 February 2019. Available online: https:/ / rosstat.gov.ru/folder/12781 (accessed on 24 May 2021). (In Russian)

27. Gerasimova, A.S.; Polyakov, S.S.; Sergiev, V.I.; Trofimov, V.T. Engineering-Geological Map of the West Siberian Lowland; Nedra: Moscow, Russia, 1968. (In Russian)

28. Abakumov, E.; Morgun, E.; Pechkin, A.; Polyakov, V. Abandoned agricultural soils from the central part of the Yamal region of Russia: Morphology, diversity, and chemical properties. Open Agric. 2020, 5, 94-106. [CrossRef]

29. Alekseeva, L. The formation of arctic agriculture in the USSR (Yamal). Bull. Nizhnevartovsk State Univ. 2017, 2, 3-10. (In Russian)

30. Morgun, E.N.; Abakumov, E.V. Agricultural research and crop yields in the Yamal-Nenets autonomous district: Retrospective analysis (1932-2019). Sci. Bull. Yamalo-Nenets Auton. Dist. 2019, 3, 4-9. (In Russian) [CrossRef]

31. Gartland, L.M. Heat Islands: Understanding and Mitigating Heat in Urban Areas; Routledge: Oxfordshire, UK, 2012.

32. Shumilov, O.I.; Kasatkina, E.A.; Kanatjev, A.G. Urban heat island investigations in Arctic cities of northwestern Russia. J. Meteorol. Res. 2017, 31, 1161-1166. [CrossRef]

33. Taha, H. Urban climates and heat islands: Albedo, evapotranspiration, and anthropogenic heat. Energy Build. 1997, 25, 99-103. [CrossRef]

34. Schuur, E.A.G.; Vogel, J.G.; Crummer, K.G.; Lee, H.; Sickman, J.O.; Osterkamp, T.E. The effect of permafrost thaw on old carbon release and net carbon exchange from tundra. Nat. Cell Biol. 2009, 459, 556-559. [CrossRef] [PubMed]

35. Shiklomanov, N.I.; Streletskiy, D.; Swales, T.B.; Kokorev, V.A. Climate change and stability of urban infrastructure in Russian Permafrost Regions: Prognostic assessment based on GCM climate projections. Geogr. Rev. 2017, 107, 125-142. [CrossRef]

36. Ji, X.; Abakumov, E.; Polyakov, V. Assessments of pollution status and human health risk of heavy metals in permafrost-affected soils and lichens: A case-study in Yamal Peninsula, Russia Arctic. Hum. Ecol. Risk Assess. Int. J. 2019, 25, 2142-2159. [CrossRef]

37. Perevozchikov, B.; Kenig, V.; Lukin, A.; Ovechkin, A. Chromites of the Rai-Iz Massif in the polar urals (Russia). Geol. Ore Depos. 2005, 47, 206-222.

38. Sidorchuk, A.; Grigorev, V. Soil erosion on the Yamal Peninsula (Russian Arctic) due to gas field exploitation. Adv. GeoEcology 1998, 31, 805-812.

39. Gordeev, V. Pollution of the Arctic. Reg. Environ. Chang. 2002, 3, 88-98. [CrossRef]

40. Shiyatov, S.; Mazepa, V. Climate. In The Nature of Yamal; Dobrinsky, L.N., Ed.; Nauka: Ekaterinburg, UK, 1995 ; pp. 32-68. (In Russian)

41. Kvashin, Y.N. Geographical Atlas of the Yamal-Nenets Autonomous District; Drofa: Moscow, Russia, 1999; p. 23. (In Russian)

42. Chistyakova, N.F. Entsiklopediya "Yamal'skiy Rayon": A-Ya [Encyclopedia "Yamal District": A to Z]; Express: Tyumen, Russia, 2015; p. 452. (In Russian)

43. Arkhipov, S.; Isayeva, L.; Bespaly, V.; Glushkova, O. Glaciation of Siberia and north-east USSR. Quat. Sci. Rev. 1986, 5, 463-474. [CrossRef]

44. Alekseev, I.; Kostecki, J.; Abakumov, E. Vertical electrical resistivity sounding (VERS) of tundra and forest tundra soils of Yamal region. Int. Agrophys. 2017, 31, 1-8. [CrossRef]

45. Food and Agriculture Organization (FAO). World reference base for soil resources 2014. International soil classification system for naming soils and creating legends for soil maps. World Soil Resour. Rep. 2014, 1, 106.

46. Black, C.A.; Evans, D.; White, J. Methods of Soil Analysis: Chemical and Microbiological Properties; ASA: Madison, WI, USA, 1965.

47. Jenkinson, D.; Powlson, D. The effects of biocidal treatments on metabolism in soil-V: A method for measuring soil biomass. Soil Biol. Biochem. 1976, 8, 209-213. [CrossRef]

48. Jackson, C.E.; Saeger Jr, C. Use of the pipette method in the fineness test of molding sand. J. Res. Natl. Bur. Stand. 1935, 14, 59. [CrossRef]

49. Kachinskiy, N.A. Mechanical and Micro-Aggregate Composition of the Soil, Methods of Its Study; MGU Press: Moscow, Russia, 1958. (In Russian)

50. EPA. Method 350.1 Determination of Ammonia Nitrogen by Semi-Automated Colorimetry. 1993. Available online: http: //www.xenco.com/pdf/tech/epa/350_1.pdf (accessed on 3 June 2021).

51. Sparks, D.L.; Page, A.; Helmke, P.; Loeppert, R.H. Methods of Soil Analysis, Part 3: Chemical Methods; John Wiley and Sons: Hoboken, NJ, USA, 2020; Volume 14. 
52. ISO 11047:1998. Soil Quality-Determination of Cadmium, Chromium, Cobalt, Copper, Lead, Nickel and Zinc in Aqua Regia Extracts of Soil-Flame and Electrothermal Atomic Absorption Spectrometric Methods; German Institute for Standardization: Berlin, Germany, 1998.

53. Cooke, G.W. The Control of Soil Fertility. Soil Sci. 1969, 108, 151. [CrossRef]

54. Foth, H.D.; Ellis, B.G. Soil Fertility, 2nd ed.Lewis CRC Press LLC: Boca Raton, FL, USA, 2020.

55. Tisdale, S.L.; Nelson, W.L. Soil fertility and fertilizers. Soil Sci. 1966, 101, 346. [CrossRef]

56. Karpova, E.; Potatueva, Y. Accumulation of heavy metals by winter rye and oat plants under the effect of nitrogen and potassium fertilizers and the long-term aftereffect of phosphorus fertilizers on soddy-podzolic soil. Agrokhimiia 2005, 4, 59. (In Russian)

57. Dube, A.; Zbytniewski, R.; Kowalkowski, T.; Cukrowska, E.; Buszewski, B. Adsorption and migration of heavy metals in soil. Pol. J. Environ. Stud. 2001, 10,1-10.

58. Sharma, R.; Agrawal, M. Biological effects of heavy metals: An overview. J. Environ. Biol. 2005, 26, $301-313$.

59. Ross, S.M. Toxic Metals in Soil-Plant Systems; Wiley Chichester: Chichester, UK, 1994.

60. Muller, G. Schwermetalle in den Sedimenten des Rheins: Veranderungen seit 1971. Umschau 1979, 79, 778-783. (In German)

61. Jiang, F.; Ren, B.; Hursthouse, A.; Deng, R.; Wang, Z. Distribution, source identification, and ecological-health risks of potentially toxic elements (PTEs) in soil of thallium mine area (southwestern Guizhou, China). Environ. Sci. Pollut. Res. 2019, 26, 16556-16567. [CrossRef] [PubMed]

62. Kowalska, J.B.; Mazurek, R.; Gąsiorek, M.; Zaleski, T. Pollution indices as useful tools for the comprehensive evaluation of the degree of soil contamination-A review. Environ. Geochem. Health 2018, 40, 2395-2420. [CrossRef] [PubMed]

63. Varol, M. Assessment of heavy metal contamination in sediments of the Tigris River (Turkey) using pollution indices and multivariate statistical techniques. J. Hazard. Mater. 2011, 195, 355-364. [CrossRef] [PubMed]

64. Hakanson, L. An ecological risk index for aquatic pollution control—A sedimentological approach. Water Res. 1980, 14, 975-1001. [CrossRef]

65. Chernova, O.V.; Beketskaya, O.V. Permissible and background concentrations of pollutants in environmental regulation (heavy metals and other chemical elements). Eurasian Soil Sci. 2011, 44, 1008-1017. [CrossRef]

66. Moskovchenko, D.V.; Kurchatova, A.N.; Fefilov, N.N.; Yurtaev, A. Concentrations of trace elements and iron in the Arctic soils of Belyi Island (the Kara Sea, Russia): Patterns of variation across landscapes. Environ. Monit. Assess. 2017, 189, 210. [CrossRef]

67. Alekseev, I.; Abakumov, E.; Petrova, A.; Vorona-Slivinskaya, L. Evaluation of the ecotoxicological state of selected soils from urban environments of Russian Arctic with the aim to substantiate reclamation and restoration strategies. In Proceedings of the International Science Conference SPbWOSCE-2017 Business Technologies for Sustainable Urban Development, Saint Petersburg, Russia, 20-22 December 2017; EDP Sciences: Les Ulis, France, 2018; Volume 170. paper No. 04001.

68. Alekseev, I.; Abakumov, E.V.; Shamilishvili, G. Heavy metals in urban soils of the Yamal region. In Proceedings of the International Conference on Landscape Architecture to Support City Sustainable Development, Moscow, Russia, 12-14 September 2016; Springer: Berlin/Heidelberg, Germany, 2017; pp. 51-56.

69. Ji, X.; Abakumov, E.; Antcibor, I.; Tomashunas, V.; Knoblauch, C.; Zubzycki, S.; Pfeiffer, E.-M. Influence of anthropogenic activities on metals in arctic permafrost: A characterization of benchmark soils on the Yamal and Gydan Peninsulas in Russia. Arch. Environ. Contam. Toxicol. 2019, 76, 540-553. [CrossRef]

70. Alekseev, I.; Abakumov, E. Permafrost-affected former agricultural soils of the Salekhard city (Central part of Yamal region). Czech Polar Rep. 2018, 8, 119-131. [CrossRef]

71. Polyakov, V.; Kozlov, A.; Suleymanov, A.; Abakumov, E. Soil pollution status of urban soils in St. Petersburg city, North-west of Russia. Soil Water Res. 2021, 16, 164-173. [CrossRef]

72. Radomskaya, V.I.; Borodina, N.A. Assessment of anthropogenic contamination in an urban territory by the example of Blagoveshchensk city. Geoecol. Eng. Geol. Hydrogeol. Geocryol. 2019, 79-93. [CrossRef]

73. Ejarque, E.; Abakumov, E. Stability and biodegradability of organic matter from Arctic soils of Western Siberia: Insights from 13C-NMR spectroscopy and elemental analysis. Solid Earth 2016, 7, 153-165. [CrossRef]

74. Keller, T.; Håkansson, I. Estimation of reference bulk density from soil particle size distribution and soil organic matter content. Geoderma 2010, 154, 398-406. [CrossRef]

75. Nasta, P.; Kamai, T.; Chirico, G.B.; Hopmans, J.; Romano, N. Scaling soil water retention functions using particle-size distribution. J. Hydrol. 2009, 374, 223-234. [CrossRef]

76. Kononova, M.A.M. Soil Organic Matter: Its Nature, Its Role in Soil Formation and in Soil Fertility; Elsevier: Amsterdam, The Netherlands, 2013.

77. Shein, E. Soil Physics Course; House of Moscow State University: Moscow, Russia, 2005. (In Russian)

78. Mineev, V. Agrochemistry; Kolos: Moscow, Russia, 2004; p. 720. (In Russian)

79. Tiessen, H.; Cuevas, E.; Chacón, P. The role of soil organic matter in sustaining soil fertility. Nat. Cell Biol. 1994, 371, 783-785. [CrossRef]

80. Kudeyarov, V.; Semenov, V. Agroecological Evaluation of Lands and Design of Landscape-Adaptive Farming Systems and Agrotechnologies: Aethodological Recommendations; Rosinformagrotekh: Moscow, Russia, 2005; p. 784. (In Russian)

81. Kiryushin, V.I. Assessment of land quality and soil fertility for planning farming systems and agrotechnologies. Eurasian Soil Sci. 2007, 40, 785-791. [CrossRef] 
82. Kiryushin, V.; Ivanov, A. Agroekologicheskaya Otsenka Zemel, Proektirovanie Adaptivno-Landshaftnykh Sistem Zemledeliya I Agrotekhnologii [Agroecological Assessment of Lands, Designing Adaptive-Landscape Farming Systems and Agricultural Technologies]. Methodological Guide; Federal State Scientific Institution: Moscow, Russia, 2005. (In Russian)

83. Holford, I.C.R. Soil phosphorus: Its measurement, and its uptake by plants. Soil Res. 1997, 35, 227. [CrossRef]

84. Yakimenko, V.N.; Institute of Soil Science and Agrochemistry of Siberian Branch of the Russian Academy of Sciences. Potassium forms in soil and methods of determination. Почвы иокружающая среда 2018, 1, 25-31. Available online: https:// soils-journal. $\mathrm{ru} /$ index.php/POS/article/view/5/5 (accessed on 24 May 2021). (In Russian). [CrossRef]

85. Arnesen, G.; Beck, P.S.A.; Engelskjøn, T. Soil acidity, content of carbonates, and available phosphorus are the soil factors best correlated with alpine vegetation: Evidence from Troms, North Norway. Arctic Antarct. Alp. Res. 2007, 39, 189-199. [CrossRef]

86. Øgaard, A.F. Effect of phosphorus fertilization on the concentration of total and algal-available phosphorus in different particlesize fractions in Norwegian agricultural soils. Acta Agric. Scand. Sect. B Plant Soil Sci. 1996, 46, 24-29. [CrossRef]

87. Sverdrup, L.E.; Nielsen, T.; Krogh, P.H. Soil ecotoxicity of polycyclic aromatic hydrocarbons in relation to soil sorption, lipophilicity, and water solubility. Environ. Sci. Technol. 2002, 36, 2429-2435. [CrossRef]

88. Lorenz, K.; Kandeler, E. Biochemical characterization of urban soil profiles from Stuttgart, Germany. Soil Biol. Biochem. 2005, 37, 1373-1385. [CrossRef]

89. Krauss, M.; Wilcke, W. Sorption strength of persistent organic pollutants in particle-size fractions of urban soils. Soil Sci. Soc. Am. J. 2002, 66, 430-437. [CrossRef]

90. Madrid, F.; Biasioli, M.; Ajmone-Marsan, F. Availability and bioaccessibility of metals in fine particles of some urban soils. Arch. Environ. Contam. Toxicol. 2007, 55, 21-32. [CrossRef] [PubMed]

91. Duruibe, J.O.; Ogwuegbu, M.; Egwurugwu, J. Heavy metal pollution and human biotoxic effects. Int. J. Phys. Sci. 2007, 2, 112-118.

92. Timofeev, I.; Kosheleva, N.; Kasimov, N. Contamination of soils by potentially toxic elements in the impact zone of tungstenmolybdenum ore mine in the Baikal region: A survey and risk assessment. Sci. Total Environ. 2018, 642, 63-76. [CrossRef] [PubMed]

93. Yang, Q.; Li, Z.; Lu, X.; Duan, Q.; Huang, L.; Bi, J. A review of soil heavy metal pollution from industrial and agricultural regions in China: Pollution and risk assessment. Sci. Total Environ. 2018, 642, 690-700. [CrossRef] [PubMed]

94. Jadhav, U.; Hocheng, H. A review of recovery of metals from industrial waste. J. Achiev. Mater. Manuf. Eng. 2012, 54, $159-167$.

95. Abakumov, E.; Shamilishvily, G.; Yurtaev, A. Soil polychemical contamination on Beliy Island as key background and reference plot for Yamal region. Pol. Polar Res. 2017, 38, 313-332. [CrossRef]

96. Gupta, S.K.; Chen, K.Y. Partitioning of trace metals in selective chemical fractions of nearshore sediments. Environ. Lett. 1975, 10, 129-158. [CrossRef] [PubMed]

97. Lavado, R.S.; Rodríguez, M.B.; Scheiner, J.D.; Taboada, M.A.; Rubio, G.; Alvarez, R.; Alconada, M.; Zubillaga, M.S. Heavy metals in soils of Argentina: Comparison between urban and agricultural soils. Commun. Soil Sci. Plant Anal. 1998, 29, 1913-1917. [CrossRef]

98. Markiewicz-Patkowska, J.; Hursthouse, A.; Przybyla-Kij, H. The interaction of heavy metals with urban soils: Sorption behaviour of $\mathrm{Cd}, \mathrm{Cu}, \mathrm{Cr}, \mathrm{Pb}$ and $\mathrm{Zn}$ with a typical mixed brownfield deposit. Environ. Int. 2005, 31, 513-521. [CrossRef] [PubMed]

99. Simon, E.; Harangi, S.; Baranyai, E.; Braun, M.; Fábián, I.; Mizser, S.; Nagy, L.; Tóthmérész, B. Distribution of toxic elements between biotic and abiotic components of terrestrial ecosystem along an urbanization gradient: Soil, leaf litter and ground beetles. Ecol. Indic. 2016, 60, 258-264. [CrossRef]

100. Gmochowska, W.; Pietranik, A.; Tyszka, R.; Ettler, V.; Mihaljevic, M.; Długosz, M.; Walenczak, K. Sources of pollution and distribution of $\mathrm{Pb}, \mathrm{Cd}$ and $\mathrm{Hg}$ in Wrocław soils: Insight from chemical and Pb isotope composition. Geochemistry 2019, 79, 434-445. [CrossRef]

101. Zhurba, O.; Rukavishnikov, V.S.; Merinov, A.; Alekseyenko, A.N. The content of petroleum products, benzo(a)pyrene and heavy metals in soils of yamalnenets autonomous district and heavy metals in the hair of children. Hyg. Sanit. 2019, 95, 521-524. [CrossRef]

102. Nizamutdinov, T.; Morgun, E.; Pechkin, A.; Kostecki, J.; Greinert, A.; Abakumov, E. Differentiation of trace metal contamination level between different urban functional zones in permafrost affected soils (the example of several cities in the Yamal Region, Russian Arctic). Minerals 2021, 11, 668. [CrossRef] 